\title{
Agama Sebagai Basis Terciptanya Etika Global
}

\author{
Oleh : \\ C.B. Ismulyadi \\ MKU-UNY \\ Email : Ismul_cokro@yahoo.com.
}

\begin{abstract}
Abstrak : Globalisasi secara umum merupakan bentuk keterbukaan dunia yang tidak lagi tersekat oleh wilayah administrasi negara, ideologi, agama, kultur budaya masyarakat dan keterpisahan geografi fisik tempat tinggal. Dunia bisa terbuka karena dipercepat oleh perkembangan teknologi komunikasi dan transportasi. Teknologi tersebut dapat menembus batas berbagai sekat-sekat dunia manusia. Melalui sarana teknologi informasi di jaman globalisasi pula, setiap orang bisa mendapatkan berita, baik dari hal yang paling dianggap tabu sampai yang paling suci sekalipun.

Agama dipaksa masuk ke dalam dan berada dunia pusaran global. Karena itu, mekanisme pasar global harus juga dipelajari oleh agama-agama, jika agama-agama masih ingin tetap eksis di dalam pusaran yang mahadahsyat ini. Sebagai contoh, meskipun pesan Kitab Suci esensinya tetap sama, masing-masing agama harus berani merumuskan secara baru apa yang menjadi pesan Kitab Suci tersebut. Atau bila perlu, ada pembaruan ajaran-ajaran agama yang sudah tidak sesuai dengan sensitivitas humanisme kontemporer. Keberadaan agama di pusaran globalisasi menuntut sebuah pilihan. Pilihan ini tidak lain adalah ketika agama menentukan langkah yang tepat agar wajahnya, minimal mengakomodasai kerinduan dari roh zaman yang bertiup di era pasar bebas dan globalisasi.
\end{abstract}

Kata Kunci : Agama, Globalisasi, Etika Global

\section{Pendahuluan}

Dalam evolusi sejarah umat manusia, ternyata perjalanan sejarah ini tidak selalu berkembang linear. Ide-ide besar datang dan pergi, gagasan yang baru menggantikan yang lama, menegasikan atau mengambil bentuk baru dari suatu sintesis kreatif yang memperkaya. Gagasan-gagasan yang tidak relevan dengan perkembangan zaman atau yang telah berperan menghancurkan zaman itu sendiri pada akhirnya akan menerima kritik, bahkan dicaci, dan lalu ditinggalkan. Hal ini memperlihatkan bahwa semakin maju capaian pemikiran manusia bukan berarti ia akan begitu saja menjamin kesejahteraan dan kedamaian manusia, meski segala upaya pemikiran itu dikerahkan untuk mencapai cita-cita. 
Misalnya gagasan-gagasan yang lahir dari kandungan globalisasi, yang merupakan antitesis dari abad pertengahan, kini menjadi sasaran kritik era sesudahnya. Kritik ini dikemukakan karena globalisasi tidak lagi sanggup menjawab problem zaman yang dinamis. Bahkan globalisasi dianggap telah menyumbangkan saham bagi lahirnya tragedi kemanusiaan yang menimpa umat manusia, seperti perang, konflik, kemiskinan, kepunahan, penindasan, pembunuhan, pencemaran lingkungan, pengangguran, inflasi, depresi, dan kekacauan iklim global.

Globalisasi memang diakui memunculkan optimisme kemajuan manusia melalui penemuan sains dan teknologi, tetapi pada sisi lain ia tidak mampu menjawab problemproblem besar yang dihasilkan dari dampak kemajuan tersebut. Banyaknya bencana kemanusiaan memperlihatkan bahwa globalisasi cenderung gagal membuat dunia semakin damai, aman, dan sejahtera.

Menurut Huntington (Huntington, 2002: ix-x), sumber utama konflik dalam era global tidak lagi ideologi atau ekonomi, tetapi budaya. Budaya akan memilah-milah manusia dan menjadi sumber konflik dominan. Negara-negara akan tetap menjadi aktor paling kuat dalam percaturan dunia, tetapi konflik politik global yang paling prinsipil akan terjadi antara bangsa-bangsa dan kelompok-kelompok karena perbedaan peradaban mereka. Benturan peradaban akan mendominasi politik global.

Secara lebih luas, dalam konteks globalisasi, Huntington mendasarkan pemikirannya - paling tidak- pada enam alasan yang dijadikannya sebagai premis dasar untuk menjelaskan mengapa politik dunia ke depan akan sangat dipengaruhi oleh benturan antar peradaban. Pertama, perbedaan peradaban tidak hanya nyata, tetapi sangat mendasar. Selama berabad-abad perbedaan antarperadaban telah menimbulkan konflik paling keras dan paling lama. Kedua, dunia ini sudah semakin menyempit sehingga interaksi antara orang yang berbeda peradaban semakin meningkat. Ketiga, proses modernisasi ekonomi dan perubahan sosial diseluruh dunia telah mengakibatkan tercerabutnya masyarakat dari akar-akar identitas-identitas lokal yang telah berlangsung lama. Kecenderungan ini menyisakan ruang kosong yang kemudian diisi oleh identitas agama, seringkali dalam gerakan berlabelkan "fundamentalisme". Keempat, dominasi peran Barat menimbulkan reaksi de-westernisasi di dunia non-Barat. Kelima, perbedaan budaya kurang bisa menyatukan, dibanding perbedaan politik dan ekonomi. Keenam, 
kesadaran peradaban bukan reason d'etre utama terbentuknya regionalisme politik atau ekonomi.

Keprihatinan terhadap tragedi kemanusiaan semacam inilah yang juga dirasakan Hans Kung, yang sebagian pemikirannya akan dibahas dalam artikel ini. Kritiknya terhadap globalisasi dengan mempertimbangkan khazanah zaman posmodernitas sekarang ini, mendorongnya untuk mencari solusi normatif bagi problem kontemporer yang diwarnai dengan teror, kekerasan, penindasan, dan bencana kemanusiaan lainnya. Tepatnya, Kung mau membangun fondasi etika bersama yang bisa menjamin kehidupan umat manusia di dunia agar lebih adil, damai, aman, dan berperikemanusiaan. Bukan etika yang semata-mata mendasarkan diri pada jenius rasio manusia, melainkan etika yang dibangun di atas nilai-nilai humanis yang terkandung dalam agama-agama. Kung meyakini, fondasi etika bersama tersebut dapat dicapai dengan jalan dialog antaragama. Pernyataan Kung yang terkenal adalah Tak ada perdamaian antarbangsa, tanpa perdamaian antaragama. Tidak ada perdamaian antaragama, tanpa dialog antaragama. (Kung, 1990: 115).

Dalam refleksi ini, pertama-tama penulis akan memaparkan kondisi global dan kritik Kung (1), lalu akan dibahas panggilan Kung akan pentingnya etika bersama untuk mengatasi problem kemanusiaan di era global (2), dan selanjutnya akan dipaparkan gagasan inti Kung mengenai keyakinannya akan nilai agama-agama sebagai basis etika global (3).

\section{Kondisi - kondisi Globalisasi}

Perbincangan tentang globalisasi (terlebih dibaca dari perspektif negeri-negeri pheriperie-istilah Wallerstein) akan mengambil dua pokok pertanyaan: apa itu globalisasi dan bagaimana impak pada dunia keseharian. Globalisasi sebagai konsep akan mengacu pada pemampatan dan intensifikasi kesadaran sebuah dunia secara keseluruhan. Perspektif ini membawa pada jantung soal perdebatan klasik (MarxWeber) antara kekuatan dominasi ekonomi dan kekuatan pluralisme sosio-kultural. Pada aras praksis, globalisasi adalah terciptanya sebuah dunia yang tanpa batas. Sebuah "trans-nasional ruang" . Tak berlebihan bila Giddens menyebut bahwa masyarakat kita dewasa ini adalah masyarakat "pengembara dalam ruang dan waktu" (Giddens, 2000:35). 
Bila perdebatan tentang globalisasi tersebut disuarakan di negeri pheriperi, yang tumbuh bukanlah perdebatan konseptual, namun sebuah perkawinan masalah antara ekonomi dan sosial-kultural. Keduanya datang bak air bah, saling tumpang tindih menggempur dunia kehidupan.

Kekuatan ekonomi yang dimotori oleh kekuatan kapitalisme, menumbuhkembangkan globalisasi produksi dan konsumsi. Sektor produksi muncul dengan tumbuhnya industri-transnasional, yang merambah mendekati pasar dan upah buruh murah. Proses ini menciptakan transnasionalisasi kapital, dan sekaligus melokalisir problem-problem sosial. Maka, apa yang kini kita kenal sebagai Neo-Liberalisme pun merambah dunia keseharian kita, memformat proses kebangsaan kita dan membuat tercabik-cabiknya bangunan-bangunan sosial lama. Kekuatan kapital telah menggulung tatanan sosial. Berbagai kasus kebijakan publik tentang politik swastanisasi pendidikan, adalah contoh nyata betapa dunia sosio-kultural berhadapan langsung dengan kekuatan pasar. Negara pun takluk menghamba pada sang tuan kapital.

Sektor produksi internasional yang berkembang menciptakan pula tingkah laku konsumtif di berbagai belahan bumi. Bahkan, negeri-negeri pheripheri justru menjadi ladang subur bagi pertumbuhan tingkah laku konsumtif, yang sering tampil sebagai gaya hidup. Scott Lash menyebutnya sebagai proses estetikanisasi dunia kehidupan. Globalisasi sektor produksi dan konsumsi, tak pelak, membawa sebuah situasi baru: polarisasi dan stratifikasi penduduk dunia dalam globalitas kaum kaya dan lokalitas kaum miskin. Polarisasi ekonomi tersebut dibarengi pula oleh adanya situasi dunia kehidupan yang terfragmentasi. Penyebabnya adalah, tidak hanya akibat dari pergeseran dari sektor produksi menuju sektor konsumsi, namun lebih dahsyat lagi adalah terjadinya konsekuensi penalaran modernitas (Ulrich, Giddens and Scott, 1997:101).

Progres, sebagai kesadaran akan waktu yang khas dalam modernitas, dimaksudkan waktu yang dihayati sebagai sebuah garis lurus menuju kemajuan. Dalam kesadaran baru ini perjalanan waktu tidak melangkah secara repetitif dan imitatif melainkan bergerak linear secara pasti. Kesadaran baru ini meyakini bahwa kekinian adalah peningkatan kualitatif atas kelampauan dan berikutnya menjadi modal peningkatan masa mendatang (Hennelly, 1995: 135)

Keyakinan akan rasionalitas manusia dan kepastian akan kemajuan ini pada momen berikutnya mengejawantah dalam aktifitas kreatif, penciptaan, dan inovasi sains 
dan teknologis. Dengan sains dan teknologi ini, umat manusia berusaha merealisasikan cita-citanya untuk menguasai alam, dan menghadirkannya untuk kesejahteraan seluruh umat manusia. Namun demikian berbagai peristiwa faktual menunjukkan realitas yang lain. Sains dan teknologi telah membawa bencana yang mahadahsyat; dua perang dunia, konflik ideologi, kemiskinan dan kelaparan, serta krisis lingkungan yang justru mewarnai optimisme modernitas ini. Dari sinilah lalu cita-cita modernitas dengan segala pranata intelektual dan sosialnya dipersoalkan. Rasio manusia yang diyakini akan membawa dunia ini menjadi lebih baik (better world) malah memupuskan harapan dan cita-citanya sendiri tentang kedamaian, kebahagiaan, dihormatinya martabat kemanusiaan.

Hans Kung, salah satu di antara sejumlah pemikir pengkritik modernitas, dengan lugas menegaskan bahwa kemajuan sains modern yang sepenuhnya bersandar pada rasio tidak seluruhnya membawa kemajuan umat manusia, begitu juga rasionalitas sains dan teknologi. Rasio pencerahan akhirnya jatuh pada irrasionalitas dan tenggelam dalam jurang kehancuran karena pemikiran saintifik dan teknologi tidak bisa memberikan dasar jawaban bagi problem-problem yang diakibatkannya. Tepatnya, pemikiran modern tidak mampu memberikan kerangka etika global untuk mengantisipasi dampak kemajuan dan perkembangan kehidupan modern sendiri yang semakin terdiferensiasi dan tersekularisasi.

Kung secara deskriptif menelanjangi cacat dan tragedi kemanusiaan yang dihasilkan oleh patologis modernitas (hilangnya tradisi dan makna hidup, hilangnya kriteria etika tanpa syarat, dll). Tragedi ini meliputi: pembunuhan dan kematian jutaan manusia akibat perang, pembunuhan, kemiskinan dan kelaparan, kerusakan dan pencemaran lingkungan oleh industri-industri besar, dan juga bencana pemanasan

global. Selain itu, dunia yang terdiferensiasi dalam bentuk negara-negara bangsa dan berbagai macam ideologi telah melahirkan konflik dan perang. Sementara sekularisasi telah menghasilkan moralitas baru yang semata-mata berdasarkan rasio atau yang dalam dunia kapitalisme didasarkan pada pertimbangan analisis pasar (Kung,

\section{Menuju Etika Bersama di Era Global}

Krisis modernitas yang membawa bencana kemanusiaan ini menarik keprihatinan Kung. Keprihatinan pertama terkait dengan tendensi modernitas yang mengandalkan 
rasio manusia yang tidak memberikan landasan etis yang memadai untuk tanggung jawab etika global. Kedua, terkait dengan budaya teknokratis yang mendominasi masyarakat modern telah mengabaikan aspek kemanusiaan dalam menggunakan teknologi. Akibatnya, bukan hanya melahirkan teknologi yang justru mengancam keadilan dan kebebasan manusia, tapi juga merusak lingkungan, bahkan ancaman terhadap eksistensi manusia itu sendiri.

Jadi, setelah manusia meluputkan diri dari cengkeraman alam, ia jatuh dalam jaringan karya dan organisasi sosial yang telah ia kembangkan sendiri. Teknologi dan birokrasi muncul sebagai kekuatan tersembunyi yang menciptakan ketergantungan dan menggarisbawahi ketakberdayaan manusia.

Bagi Kung, untuk menghindari bencana yang barangkali akan semakin membesar ini, tidak bisa tidak harus ada suatu pergeseran nilai dalam paradigma kehidupan manusia. Pergerakan dari nilai-nilai modernitas ke "paska modernitas" ini meliputi halhal berikut. Pertama, perubahan dari masyarakat yang bebas etik menuju masyarakat yang bertanggung jawab secara etis. Kedua, dari budaya teknokrasi yang mendominasi manusia menuju teknologi yang melayani manusia. Ketiga, dari industri yang merusak lingkungan menuju industri yang ramah lingkungan, dan keempat, dari demokrasi legal menuju demokrasi yang berkeadilan dan berkebebasan. (Kung, 1991: 20-21).

Namun demikian realisasi pergeseran paradigma ini tentu saja membutuhkan konsensus bersama, suatu moralitas atau norma etik yang mengikat secara universal. Yakni, suatu norma dan nilai minimum yang bersifat transkultural dan transnasional yang bisa menjamin dan mengarahkan umat manusia menuju kehidupan masa depan yang harmonis, damai, taat hukum, dan tanpa kekerasan. Suatu norma yang dilandasi oleh tanggung jawab bersama terhadap kehidupan alam semesta (a planetary responsibility). Norma ini adalah etika publik-global yang bertanggung jawab terhadap orang lain, lingkungan dan masa depan dunia, serta menjadikan manusia sebagai kriteria dan tujuan. (Kung, 1991:28-35).

\section{Agama-agama sebagai Basis Etika Global}

Pertanyaan pertama untuk membangun sebuah etika bersama adalah: di atas landasan apa etika bersama dan mengikat itu hendak dibangun? Apa kriteria validitas etika bersama itu agar bisa dipertanggungjawabkan secara bersama-sama pula? 
Pertama-tama Hans Kung mengaskan bahwa kemajuan sains modern tidak seluruhnya membawa kemajuan umat manusia, begitu sains dan teknologi tidak seluruhnya rasional. Rasio pencerahan toh akhirnya jatuh pada irasionalitas dan tenggelam dalam jurang kehancuran. Karena persis pemikiran saintifik dan teknologis modern tidak bisa memberikan dasar bagi nilai-nilai universal, hak asasi manusia (HAM), dan kriteria etis yang memadai.

Kedua, filsafat juga gagal bahkan tidak mampu memberikan fondasi etika praktis bagi seluruh masyarakat, juga suatu etika yang bersifat universal dan mengikat. Alihalih, mereka (para filsuf seperti MacIntyre, Rorty, Foucault, dll) kembali pada budaya dan nilai-nilai lokal sebagai sumber norma-norma etika yang tentu bagi Kung partikularitas itu tidak mencukupi bagi etika bersama. Mengapa demikian? Karena rumusan etika dalam filsafat tidak menyertakan keharusan universal dan yang tanpa syarat. Filsafat hanya mengabdi pada kekuatan rasio sehingga ketundukan pada keharusan etis terasa menyakitkan secara eksistensial. Apalagi juga filsafat mustahil menuntut pengorbanan atas kepentingan hidup mereka.

Dengan bersikap pesimis terhadap peran rasio dan filsafat yang gagal menyediakan fondasi etis, Kung akhirnya melirik peluang agama yang secara potensial bisa menjadi dasar pijakan bagi moralitas universal semacam itu. Memang benar bahwa agama bisa berlaku otoritarian, menjadi tiran, menciptakan intoleransi, ketidakadilan, isolasi dan seterusnya hingga memusuhi sains, teknologi, industri, bahkan demokrasi dan HAM. Namun demikian, Kung menyanggah kalau agama dianggap tidak memiliki masa depan. Bagi Kung, agama adalah fenomena universal manusia. Ia adalah dimensi esensial hidup dan sejarah manusia yang tidak mungkin tergantikan oleh ideologi lain, apakah humanisme ateistik ala Feurbach, sosialisme ateistik ala Marx, sains ateistik ala Freud dan Russel, atau yang lain. Memang benar bahwa agama juga telah menyebabkan destruksi, tapi kenyataanya agama juga membawa pembebasan manusia, ikut menyumbangkan nilai-nilai keadilan, toleransi, solidaritas, demokrasi, HAM, perdamaian dunia, dan seterusnya, bahkan menjadi kekuatan etika nonkekerasan (Kung, 1991:46). Bagi Kung, dengan bukti-bukti bahwa agama bisa menjadi fondasi bagi identitas psikologis, kedewasaan manusia, kesadaran diri yang sehat serta kekuatan pendorong perubahan sosial, Kung menolak agama dipandang sebagai proyeksi atau sarana pelipur lara, apalagi ilusi kekanak-kanakan. 
Sebaliknya, agama memiliki harapan dan potensi besar untuk membangun kerangka etika universal, yang tidak mungkin lagi diharapkan dari rasio dan pemikiran saintifik dan teknologis. Mengapa? Pertama, setiap agama memiliki nilai-nilai humanum, dam justeru ia bisa dipertanggungjawabkan karena nilai-nilai humanis ini. Kedua, agama memberikan basis absolutisitas dan keharusan moral secara tepat tanpa syarat, dimanapun, kapanpun, dan dalam hal apapun. Ini berbeda dengan para penganut ateisme, mereka bisa saja melakukan tindakan bermoral secara otonom dan manusiawi tetapi mereka tidak bisa memberikan alasan mengapa ia menerima absolutisitas dan universalitas kewajiban moral. Kung menegaskan: "An inconditional claim, a 'categorical' ought, cannot be derived from the finite conditions of human existence, from human urgencies and needs. And even an independent abstract 'human nature' or idea of humanity' (as a legitimating authority) can hardly put unconditional obligation on anyone for anything" (Kung,1991: 52). Sebaliknya, tuntutan etis dan keharusan tanpa syarat itu hanya bisa dan harus didasarkan pada sesuatu yang tak bersyarat dan yang absolut.

Dalam konteks ini, bagi Kung, agama-agama bisa memberikan basis tuntutan etis yang absolut dan universal. Keyakinan pada the Ultimate Reality atau Tuhan diyakini bisa memberikan motivasi moral dan tingkat paksaan (compulsion), dan menjadi modal dasar agama-agama dalam membangun etika bersama. Dan alasan ketiga, etika global yang bersifat universal berdasarkan nilai-nilai agama mungkin dicapai karena setiap manusia secara antropologis meyakini akan Yang Absolut.

Namun demikian Kung memberikan sejumlah catatan bahwa agama-agama seharusnya juga bersikap rendah hati menerima perkembangan pemikiran baru karena ia sendiri tidak lepas dari problem di dalam dirinya. Singkatnya, agama tetap tidak bisa mengabaikan nilai-nilai pencerahan seperti humanisme, perkembangan sains dan teknologi. Beberapa alasan yang dikemukakan Kung, antara lain; pertama, karena nilai dan norma etis konkret itu juga hadir bersama dalam proses sejarah, maka dimungkinkan solusi dan norma etis itu berubah secara kontekstual. Kedua, agamawan juga harus menggunakan bantuan metode sains untuk memperoleh kepastian analisis secara prejudis terhadap persoalan-persoalan terkait sebelum mengambil keputusan. Ketiga, persoalan yang semakin kompleks menuntut adanya pertanggungjawaban etis berikut solusi konkrit menurut konteks setempat. Selain itu tindakan etis juga mesti 
dilakukan dengan pertimbangan prioritas dan kepastian, dan ini bisa dicapai dengan memanfaatkan metode analisis sains.

Dengan menjadikan agama-agama sebagai basis etika global ini, Kung benarbenar ingin mencari alternatif landasan bersama etika bersama yang mengikat. Bukan menggantungkan diri pada rasionalitas manusia, melainkan pada pertemuan nilai-nilai humanis dari agama-agama.

Gagasan etika global Kung tidak mengarah pada revivalisme keagamaan, apalagi yang sektarian. Melainkan Kung hendak merumuskan etika global yang bisa menjamin kepastian dan keharusan moral bagi semua orang. Bagi Kung, kriteria etika semacam itu hanya mungkin ditemukan dalam agama-agama. Mengapa? Sebagaimana disinggung di atas, unsur dasar agama adalah keyakinan adanya otoritas absolut yang transenden. Dan kepercayaan terhadap realitas transenden merupakan gejala atau fenomena universal manusia. Hanya etika transenden yang berasal dari otoritas absolut itulah yang bisa menjamin kepastian nilai-nilai tertinggi, norma-norma tak bersyarat, motivasi terdalam, serta ideal-ideal tertinggi. Dan dalam setiap agama, tegas Kung, ada nilai-nilai etis bersifat universal yang bisa dipakai sebagai landasan bersama.

Jadi, alih-alih mau menyerukan ke revivalisme agama atau sektarianisme, Kung justru mengafirmasi potensi agama-agama untuk membangun landasan etis bersama bagi perdamaian global. Agama bukanlah suatu hypostase (Kleden, 1985:215). Agama tidak tinggal dalam dunia Platonik, tetapi merupakan agama manusia biasa dengan daging dan darah. Suatu agama yang menyejarah yang berjuang bersama perubahan dan kefanaan, dan terlibat dalam menyelesaikan krisis dan keprihatinan umat manusia.

\section{Penutup}

Dari beberapa pandangan dan tanggapan singkat yang dapat ditegaskan mengenai posisi Hans Kung terutama terkait dengan gagasan mengenai agama sebagai fondasi etika global adalah:

Pertama, Hans Kung berupaya mencari landasan etika bersama yang bersifat universal, memiliki kepastian absolut dan mengandung tuntutan yang mengharuskan. Menurut dia, etika yang berasal dari rumusan rasio manusia tidak bisa menjamin nilai etika seperti itu karena manusia terbatas. Manusia yang terbatas dan tindakannya ditentukan oleh kebutuhan-kebutuhannya mustahil melahirkan norma etis yang bersifat 
universal dan tidak bersyarat. Karenanya hanya satu penjamin nilai-nilai itu, yakni zat yang tidak terbatas dan tidak bersyarat: Tuhan atau Realitas Ultim.

Kedua, Hans Kung menjadi salah satu ikon dialog antaragama yang diharapkan menyatukan, bukan menyeragamkan, agama-agama melalui keprihatinan bersama. Dengan ini, dialog bukan sebatas masalah teologis tapi merambah dan terlibat penuh pada wilayah dan persoalan-persoalan sosial, ekonomi, politik dunia. Etika yang digagas Kung lahir karena ada tanggungjawab global yang diemban agama-agama.

Melalui gagasan agama sebagai basis etik global, setidak-tidaknya Hans Kung menampik anggapan yang mengemuka, yakni ketika kemajuan global dan sekularisasi telah menyingkirkan peran penting agama di ranah publik.

\section{Daftar Pustaka}

Giddens, Anthony. 1990. The Consequences of Modernity, Stanford, California, Stanford University Press.

Gramedia Pustaka Utama.

Hennelly, Alfred T. 1995. Liberation Theologies: The Global Pursuit of Justice, Twenty-Third Publications.

Hardiman, F. Budi. 2003. Melampaui Positivisme dan Modernitas, Yogyakarta. Kanisius.

Huntington, Samuel. 2002. The Clash of Civilization. Foreign Affair, Summer.

Kung, Hans. 1991. Global Responsibility In Search of a New World Ethic. New York. Crossroad Publishing Company.

Kleden, Ignas. 1985. "Agama dalam Perubahan Sosial” dalam Agama dan Tantangan Zaman. Jakarta. LP3ES.

Ulrich, Bec. ; Giddens, Anthony and Lash, Scott., 1997. Reflexive Modernization: Politics, Tradition and Aesthetics in the Modern Social Order. London. Polity Press. 